\title{
Research on University English Teachers' Role Orientation in the Environment of Multimedia Network
}

\author{
Haiyan Gu \\ Xi'an International University, Xi'an Shaanxi, 710077, China
}

Keywords: Individualized and autonomous, New requirement, Self-access English learning, Teacher's role.

\begin{abstract}
The rapid development of multimedia technology and the network technology led to the new University English teaching mode which is individualized and autonomous and make multimedia network technology as the platform. This new teaching mode raised new requirement to the teacher. The aim of this paper, based on autonomous learning theory and combined with the university self-access English learning, discusses the teacher's role played in university English autonomous learning, so that teachers can better guide the students and help students effectively carry on the independent study.
\end{abstract}

\section{Introduction}

With the rapid development of the information technology and Internet technology, the college English teaching mode is facing a profound information revolution. Multimedia network technology, the new teaching means, changed the traditional teaching mode for a long time with the teacher as the center, simple teach language knowledge, and established with students as the center, multimedia and network for auxiliary means of new teaching mode. But at the same time, it is a double-edged sword, and the teacher should play the students' subjective effect, and optimize the teaching process from the start, and strictly follow the practicability, appropriateness, comprehensive and auxiliary and heuristic principles, etc, to provide better service for college English teaching.

\section{The Present Situation of University English Teaching in the Context of Multimedia Network}

The present situation of University English teaching in the context of Multimedia Network is mainly reflected as follows:

\section{Making Full Use of Multimedia Resources to Develop the Stereoscopic Teaching Materials}

Multimedia teaching is the multimedia computer aided teaching, using multimedia computer integrated processing and control symbols, language, text, voice, graphics and image and other multimedia information, the each element according to the teaching requirements of organic integration, and through the matching device projection to display. In recent 50 years, network, multimedia is changed into classroom teaching as a major feature of modern education.

Scenario is the learners' social and cultural background to study and practice. In China, students learn English in non-native environment, so the most is the lack of vivid heard and convenient situational English environment. Different from a teacher, a book, a piece of chalk in the traditional teaching, multimedia technology can effectively set a variety of audio and video elements, and effects on the students listen, say, the different senses. When the teacher gives lessons, we can use multimedia platform interspersed with conversation, news, original sound movie clips, video data, to enable students to understand the image details, true, colloquial multidimensional information, thereby greatly make up the lack for our daily teaching activities in the English language environment. 


\section{Fully Mobilizing the Main Body's Enthusiasm of Study and Establishing the Interaction Teaching Mode of the Teachers and Students}

Education experts say that good teaching should make students learn fast, cheerful and thorough. The application of multimedia technology make a boring learning materials concrete, visualize, authenticity, and it breaks through the traditional teaching mode of the limits of time and space and maximize the implementation of personalized learning, and establish the students' main position in the course of teaching. At the same time, students can also obtain the freedom to choose different levels of learning materials, and set their own objectives, and constantly adjust according to its own needs and level.

In addition, this new teaching model has abandoned passive teaching of the teacher-centered "chalk and talk "type, making students become the active participants in the learning process. The role conversion of the whole teaching process between the teachers and students make students become a process of interaction between them. Once the communication among students in space has been opened, the time that they participate in the classroom activity would increase substantially. For example, the teacher let the students improvised dialogue through multimedia devices, dictation exercises, group discussions and other activities, on one hand, lifting the students communicate in English when the presence of a mental disorder; on the other hand, teachers can monitor the whole class or individual group activities, and make proper guidance and adjustment. Visible, it not only conforms to the foreign language study cognitive regularity, and will guide college English Teaching in the personalized learning and independent learning direction.

\section{Transformation of Teachers' Role}

"Autonomous Learning" is a term first by Henri Holec in his "Autonomy and Foreign Language Learning ". He was also the first people to combine autonomous learning with foreign language teaching. From him Autonomous Learning is a pair of his learning ability".

Modern education should take the cultivation of students' lifelong learning for autonomous learning ability as the first goal; University English teaching should also take the cultivation of students' Autonomous English learning ability in the first place. But according to investigation, at present, due to various factors, now some universities university English teachers cannot easily change their roles, in order to promote the effective development of students' Autonomous learning.

The survey shows, there are a lot of university English teachers are awareness of the autonomous learning, and simply think that autonomous learning is the students' learning, and teachers have little relationship. There are some teachers have a certain understanding to the autonomous learning models, but they are not given the necessary guidance, and there are no clear teaching objectives, not cultivating students' autonomous learning context, so it cannot achieve the desired results. As a mode of autonomous learning subjects -- students to recognize the importance and necessity of autonomy learning, but many students' learning objectives are not clear, and they give too much expectation to teachers and English classroom, and are lack of application of multimedia technology in classroom teaching advantage initiative, and their class participation is low, without learning plan, to cultivate autonomous learning as the goal of the student centered classroom completely indifferent. In conclusion, the present situation of students' autonomous learning ability has many deficiencies, and autonomous English learning in the modern English teaching has not been effectively carried out, and the whole of the teacher's roles is not entirely student ideal role, in order to improve the current situation, teachers should constantly improve their own teaching objectives, clear and teaching plan to redefine its role.

\section{Role Localization under the Environment of Multimedia Teaching in University English Teaching}

The traditional university English class mainly takes the teacher as the center, and the teacher is infusion, and the initiator of the knowledge. However, along with the time and the development of science and technology, the traditional teaching mode has been more and more inadapt to the society 
and students' new request. First of all, students' English level is uneven, and the teacher neat and tidy teaching to meet different levels of students demand; Secondly, with class sizes expanding gradually, it not only results in the decline of the teaching efficiency, but also brought difficulties for teachers to organize effective classroom activities; Third, along with the network popularization, the students prefer the use of video and image, and other ways to get information; Finally, learning material rich variety, and causes greatly reduces for the student to teacher's dependence. Under such a background of taking the network as a platform, but the college English autonomous learning arises at the historic moment, so, in this new study mode, the teacher should play what role by which teachers can better guide the student to carry on the effective autonomous learning?

\section{The Teacher is the Teachings' Designer}

Because of the influence of the traditional teaching mode, the students often to the teacher to have a certain degree of dependence, namely the teacher teach what and students learn what, and they study are not clear about the content and the way to learn. Therefore, the teacher in the network autonomous learning should be in accordance with the requirements of teaching outline, combining students' actual level, and formulating learning tasks for students to help students set practical learning strategies and learning plan.

First of all, in the network autonomous learning, strategies and methods of teaching is a very important point for the teacher. Although college students has certain ability of self-study, but really improve the acquisition and processing information ability, but also understand and master all kinds of English learning strategies. Therefore, in college English network autonomous learning, teachers should be based on the specific circumstances of the students, and introduce students learn strategies, such as listening learning strategies, reading, learning strategies, writing learning strategies, translation skills and methods, etc., and train students to the flexible choice and use suitable learning strategies. At the same time, teachers can carry out in the class about learning strategies of discussion, and recommend the English learning successful strategy to the class. Only by making students understand and master all kinds of learning strategy and method, then they can better cultivate students' autonomous learning ability, and improve the learning efficiency. Second, at present our country college students' English level is uneven, and the coastal area cities open early English class, so students' English foundation is good, but the vocabulary is bigger, and listening and oral English ability are relatively good.

Therefore, for different foundation and different learning ability of students, the teacher should help them design level of study plan, and let students in different levels independent setting the time to study and progress according to one's own power to meet the students' different learning needs, and to help them better network autonomous learning.

\section{The Teacher is the Guider and the Supervisor}

In order to guarantee the network autonomous learning effects, the teacher should supervise the whole process of learning autonomous learning. This oversight is not requiring teachers to monitor students' every act and every move, but through a certain means to check the monitor students' progress and learning effect. Teachers can use network autonomous learning platform, depending on the actual situation of the students for the setting of learning process, and monitor their learning progress. In the used "new field of vision university English network learning system " as an example, the teacher can on the learning process as follows: hearing set objective questions cross the boundary conditions: submitting answers to exercises and the correct rate is at least $70 \%$ fill in the blanks; oral clearance conditions: in accordance with the speech recognition rate is at least $60 \%$ units for each exercise; for the listening and vocabulary quiz the correct rate of at least $60 \%$ : each unit test. In the learning mode, the role of teachers is the supervisor, students are learning to master, so as to guarantee the students' learning progress, but also changed the traditional classes and rigidly uniform malpractice.

At the same time, the teacher can also by viewing the learning effect of students to realize supervision. For example, regularly checking the learning records, log, job submission, learning time, 
discuss data. Based on the students' independent learning supervision, teachers can understand students' autonomous learning dynamic, process, effect, and to help students adjust learning programs, and to urge the students to complete learning content.

\section{The Teacher is Teaching's Guider and Evaluator}

Network autonomous learning process requires teachers to study effect evaluation. For teachers, only by making the correct assessment for students' autonomous learning effect, we can continue the next step of the concrete teaching; for autonomous learners, evaluation is the judgments of the effect of learning tools, and help learners in the learning process for reflection. Teachers should research more on the evaluation and assessment content to find the effective method and way.

Evaluation mode. time, space, content, way and progress of "autonomous learning " has certain flexibility and autonomy, therefore, English autonomous learning assessment way there are three main types: self-assessment, teacher assessment and peer assessment. In this evaluation model, the role of teachers is not only assessed for autonomous learners were, but also to supervise the autonomous learners self assessment and guidance of autonomous learners of mutual evaluation.

Assessment content. Assessment content includes online learning records, online homework, online test and teachers' teaching record. "Online learning record " refers to teachers through a system of " process management " for students in network platform self-study activity time, frequency, and browse content and correct rate etc.. Teachers can evaluate according to learning on students' learning attitude and learning conditions.

"Online operations" is the task that teacher design through the network platform design of electronic item and requiring students to use network resources to complete listening, speaking, reading and writing. The teacher may according to the teaching contents set up an operation type, job content and request, submit way, etc. Our use of the "new horizon college English online learning system" contains various forms of online exercises, such as imitation, to read, and fill in the blanks, attachment, selection, sorting, etc., so teachers can pertinently require students to complete the study task.

"Online test" is online testing item pool of autonomous learning platform own, and college English placement test papers and teachers using network teaching platform of production test. Online testing is an important content of college English network autonomous learning evaluation, and it can not only help students diagnosis learning effect, also can help the teacher analysis autonomous learning appeared in the deficiency and establish corresponding strategy. "The teacher imparts the record" refers to the teacher through students in the surface performance of teaching for students to make evaluation. After independently completing the teaching content, the teacher evaluate students' oral English level by letting students group dialogue, role playing, etc.

\section{The Teacher is Teaching's Ministrant and Reflective}

Because the network independent study is still at the starting stage, so students will encounter various problems in the learning process. For example, some students do not understand the characteristics of network learning and method, and cannot make full use of online learning resources; some students do not adapt to the network learning environment, and be prone to impatience, confused mood; some students chat on the Internet in learning time, and cannot use time reasonably and efficiently; Some of the students in independent learning problems, cannot obtain help and guide. Therefore, teachers should serve as mentors, collaborative roles, to the students to provide the necessary support, help. The teacher can through the E- mail, BBS, Q\&A discussion forum, class listening autonomous learners in the learning process problems, to provide suggestions to solve the problem, to help learners to eventually find a solution to the problem. To be a helpful collaborator of students, teachers should not only learn the language and the language teaching itself, learning methods, but also understand students past and present learning situation, understanding the social requirements for students, as well as understanding to target pathways. This overall demand analysis, we can be independent learners to provide useful suggestions, to become a good helper, collaborators. 


\section{Conclusion}

The independent learning of the University English by Network as a platform changes the traditional teacher-centered teaching model, to promote self-study, cooperative learning by teaching mode. This new teaching mode raised new requirement on the part of the teacher. The role of the teacher is no longer a simple " Professor" and " indoctrination ", but to play the designers, supervisors, assessment, collaborative roles. Teachers must fully realize its role, and help students form good learning habits, so the students' learning behavior extends to the outside of the classroom, to adapt to this new teaching mode -the university English autonomous learning, which plays an important role in teaching and improving students' autonomous learning ability.

\section{References}

[1] Jeremy Harmer, How to teach English, 2000, Foreign Language Teaching and Research Press, the whole book.

[2] Scrivener, J. Learning Teaching, 2002, Shanghai Foreign Language Education Press, introduction part.

[3] Shrum, J. L. \& Glisan, E. W., Teacher's Handbook, 2003, Foreign Language Teaching and Research Press, Chapter 2.

[4] Silberstein, S., Techniques and Resources in Teaching Reading, 2002, Shanghai Foreign Language Education Press, P3-18, 101-111.

[5] Ur, P. A Course in Language Teaching: Practice and Theory, 2000, Foreign Language Teaching and Research Press, Module 10 .

[6] Harmer, J., The Practice of English Language Teaching new edition, 1991, Longman, Chapter 10 .

[7] Nunan, D., Second language Teaching and Learning, 2001, Foreign Language Teaching and Research Press, Chapter 9 .

[8] Anderson, N. J., Exploring Second language Reading, 2003, the whole book.

[9] Cohen, A. D., Assessing language Ability in the Classroom, 2005, Foreign Language Teaching and Research Press, Chapter 7.

[10] Scrivener, J. Learning Teaching, 2002, Shanghai Foreign Language Education Press, Chapter.

[11]Nunan, D., Second Language Teaching and Learning, 2001, Foreign Language Teaching and Research Press, Chapter 9 .

[12]Ur, P. A Course in Language Teaching: Practice and Theory, 2000, Foreign Language Teaching and Research Press, Module 9. 